ABHANDLUNGEN

Berufe, Digitalisierung und Globalisierung

\title{
Examining the Relationship Between Digital Transformation and Work Quality: Substitution Potential and Work Exposure in Gender-Specific Occupations
}

\author{
Katharina Dengler $\cdot$ Anita Tisch
}

Published online: 13 July 2020

(C) The Author(s) 2020

\begin{abstract}
Computers can substitute for many tasks currently performed by humans and are likely to change occupations in the near future. However, it is not likely that entire occupations will disappear. In this context, little attention has been paid to possible impacts of digital transformation on aspects of work quality. It would be desirable for changes to ease occupations with high work exposure. In this article, we assume that digital technologies may replace physically demanding jobs mainly performed by men, but not psychosocially demanding jobs mainly performed by women. Thus, the question arises whether social inequality between men and women may increase in the course of digital transformation. Using largescale administrative and survey data from Germany, we analyse the relationship between digital transformation and work exposure for male- and female-dominated occupations. We measure the degree of digital transformation by occupation-specific substitution potential, that is the extent to which occupational tasks can be replaced by computers or computer-controlled machines. The results imply that digital technologies could relieve men of physically demanding jobs. However, we cannot find any evidence that digital technologies have already caused employment to decline in occupations with physical work exposure.
\end{abstract}

Keywords Technological change $\cdot$ Automation · Work load · Gendered occupations · Germany

Online Appendix: www.kzfss.uni-koeln.de/sites/kzfss/pdf/Dengler_Tisch.pdf

K. Dengler $(\bowtie)$

Institute for Employment Research

Regensburger Straße 104, 90478 Nuremberg, Germany

E-Mail: Katharina.Dengler@iab.de

A. Tisch

Federal Institute for Occupational Safety and Health

Friedrich-Henkel-Weg 1-25, 44149 Dortmund, Germany

E-Mail: Tisch.anita@baua.bund.de 


\section{Der Zusammenhang zwischen Digitalisierung und Arbeitsqualität: Substituierbarkeitspotenzial und Arbeitsbelastung in geschlechtsspezifischen Berufen}

Zusammenfassung Computer können viele Aufgaben ersetzen, die derzeit noch von Menschen ausgeführt werden, und werden Berufe höchstwahrscheinlich in naher Zukunft verändern. Es ist jedoch unwahrscheinlich, dass ganze Berufe verschwinden werden. Bislang wird den möglichen Auswirkungen der Digitalisierung auf die Arbeitsqualität wenig Aufmerksamkeit geschenkt. Es wäre wünschenswert, wenn die Veränderungen im Zuge der Digitalisierung dazu führen, dass Berufe mit hoher Arbeitsbelastung entlastet werden. In diesem Artikel gehen wir davon aus, dass die digitalen Technologien physisch anstrengende, hauptsächlich von Männern ausgeübte Tätigkeiten ersetzen können, nicht aber psychosozial anstrengende, hauptsächlich von Frauen ausgeübte Tätigkeiten. Daher stellt sich die Frage, ob die soziale Ungleichheit zwischen Männern und Frauen im Zuge der digitalen Transformation zunehmen könnte. Anhand von umfangreichen administrativen Daten und Befragungsdaten aus Deutschland analysieren wir den Zusammenhang zwischen Digitalisierung und Arbeitsbelastung für Männer- und Frauenberufe. Den Grad der Digitalisierung messen wir mithilfe von berufsspezifischen Substituierbarkeitspotenzialen, d.h. das Ausmaß, in dem berufliche Tätigkeiten bereits durch Computer oder computergesteuerte Maschinen ersetzt werden können. Die Ergebnisse deuten darauf hin, dass digitale Technologien Männer von körperlich anstrengenden Tätigkeiten entlasten könnten. Wir finden jedoch keine Hinweise darauf, dass die digitalen Technologien bereits zu einem Rückgang der Beschäftigung in Berufen mit physischer Arbeitsbelastung geführt haben.

Schlüsselwörter Technologischer Wandel · Automatisierung · Arbeitsexposition · Geschlechtsspezifische Berufe · Deutschland

\section{Introduction}

In the current debate on the increasing dissemination of digital technologies, it is assumed that digital transformation is associated with disruptive social and economic consequences for the labour market. Most prominent is the debate about the automation of jobs (Frey and Osborne 2017). However, recent studies show that rather than losing entire jobs, it is more likely that the occupational landscape will change fundamentally, with tasks changing within an occupation (Arntz et al. 2017; Dengler and Matthes 2018a). Furthermore, new occupations and tasks may arise owing to technological progress.

In this debate, little attention has been paid to the impact of digital transformation on the central aspects of work quality (Kirchner 2015) or the human structuring of workplaces (Guhlemann et al. 2018). In this respect, it has been argued that the occupational change driven by digital transformation may create an increasing number of occupations with low work exposure and eliminate (physically) demanding tasks. Accordingly, Reinert (2016) states that the digital transition brings along many op- 
portunities to make work safer, healthier, more flexible and more socially inclusive. It has further been argued that especially demanding tasks performed by employees today will be conducted by computers in the near future (e.g., Ahlers 2016).

Another controversial issue is the impact of the ongoing digital transformation on the existing occupational gender segregation. Although some authors emphasise the opportunities digital technologies afford for the participation of both sexes in employment and for a more gender-integrated distribution of work, they note the lack of a gender-related perspective on processes of digital transformation in workplaces (Kutzner and Schnier 2017; Lott 2016). On the one hand, men and women face different work exposure and concomitant risks in terms of occupational safety and health. Although male-dominated occupations are often associated with higher (physically) work exposure, women perform jobs that are often wrongly assumed to be safe and easy (EU-OSHA 2018). On the other hand, most recent studies show that relative to men, women on average are less likely to be substituted by digital technologies (Dengler and Matthes 2016). Against this background, this article discusses the relationship between the substitution potential of occupations in the course of digital transformation and work exposure in gender-specific occupations. Thus, the central questions of this article are whether substitution by digital technologies is related to work exposure in certain jobs and to what extent this substitution applies equally to men and women.

To answer these questions, we combine information from different data sets at the occupational level. Based on administrative data drawn from the IAB Employment History $(\mathrm{BeH})$, we distinguish between male-dominated, female-dominated and gender-integrated occupations. We combine this information with data on substitution potential, which is calculated based on the occupational expert database BERUFENET and describes the extent to which occupations are replaceable by computers or computer-controlled machines. Furthermore, data on occupation-specific work exposure, obtained from the BIBB/BAuA employment survey, have been linked. To our knowledge, the analyses carried out are the first to elucidate the relationship between possible substitution due to digital transformation and existing work exposure. Furthermore, we also analyse the extent to which substitution potential and work exposure are related to occupation-specific employment growth.

\section{Theoretical Considerations and Previous Findings}

\subsection{Digital Transformation and Shifting Work Exposure}

The impact of digital transformation on employment has been studied comparatively well. Based on the automation probabilities of occupations, Frey and Osborne (2017) calculated the expected impact on employment. Assuming that computers can replace entire occupations, they argued that within the next 10 to 20 years, nearly half of employees in the USA will be substitutable by machines. The study has been frequently quoted and often criticised. The main points of criticism are that employees in the same occupation do not necessarily perform the same tasks and that it is primarily tasks that are being automated, not entire occupations (Arntz 
et al. 2017; Dengler and Matthes 2018a). Studies assuming that only certain tasks of an occupation can be substituted by computers or computer-controlled machines arrive at lower values. Arntz et al. (2017) show that only 9\% of US employees will be substitutable by machines in the next 10 to 20 years. Similar studies for the German labour market reveal values of approximately 15 to 25\% (Arntz et al. 2016; Dengler and Matthes 2018a, 2018b).

Studies such as those by Dengler and Matthes (2018a, 2018b) point out that fears of massive job cuts due to digital transformation are currently unfounded. Rather, the main challenge of the digital transformation is the rapidly changing industry and occupational structure. Occupations and occupational tasks will change fundamentally. As a consequence, this fundamental change in tasks should also affect work exposure.

In fact, over the last few centuries, occupational safety has increased in Germany and beyond. Technical innovations, as well as occupational health and safety management, have helped to reduce accidents at work and have made jobs safer (Brenscheidt et al. 2018). Accordingly, owing to automation, employees have already experienced a significant reduction in physical demands. This trend seems to continue in the current digital transformation. Employees report that physical work requirements are decreasing as a result of the ongoing substitution in the digital transformation. This physical relief is especially strong among employees with lower educational levels and those performing physically demanding tasks (Arnold et al. 2016). As physically demanding tasks seem to have an ongoing potential for substitution, we state the following hypothesis:

H1 The potential for substitution is positively associated with physical work exposure.

At the same time, a growing body of literature discusses how new technologies entail new forms of risks to occupational safety and health, mainly because of the psychosocial demands of tasks (Adolph et al. 2016). However, only a small number of studies focus on the direct impact of new technologies on working conditions or health outcomes; findings on the possible influences of the digital transformation on work exposure and psychosocial health are still inconclusive (Müller-Thur et al. 2018).

Accordingly, it is frequently observed that progressive digital transformation is accompanied by growing uncertainty and intensified work in many occupations. Flexible forms of employment and the rise of job insecurity can both be attributed to organisational restructuring following the introduction of new technologies. Köper and Richter (2016) demonstrate that restructuring, especially restructuring in combination with the introduction of new technologies, is positively associated with psychological stress. Previous studies emphasise that job insecurity explains most of the negative association between restructuring and psychological health (Mohr 2000). Additionally, a vast amount of literature emphasises the negative relationships between flexible forms of employment and insecurity, working conditions, psychological well-being and health outcomes (Büssing 1987; Ferrie 2006; Kroll and Lampert 2012; Quinlan et al. 2001; Tophoven and Tisch 2016). 
Moreover, tasks are becoming more diverse and complex, and increasing amounts of information must be processed at short notice (Böhm et al. 2016). Working contexts are changing and are characterised by faster and more direct communication. In addition, production, service and communication processes are continuously accelerating as the complexity of tasks increases (Rosa 2005). Consequently, qualitative and quantitative work intensification, both of which are associated with the wellbeing of employees, increases (Stab and Schulz-Dadaczynski 2017). First empirical studies show a negative association between technological change and work intensification (Ahlers 2016; Arnold et al. 2016; Holler 2017; Meyer and Hünefeld 2018). Further studies indicate that the use of new technologies not only increases intensification but is also associated with increased stress levels (Kirchner 2015), emotional exhaustion (Böhm et al. 2016), information overload and several health complaints (Junghanns and Kersten 2019). Meyer et al. (2019) show not only that the introduction of new technologies is associated with increased work intensity but also that new technologies moderate the association between working conditions and psychosomatic health complaints. In addition to work intensification, some authors find that flexible forms of employment, such as fixed-term or temporary agency jobs, as well as job insecurity, increase as new technologies emerge (Gallie et al. 2017; Sparks et al. 2001).

Hence, psychosocially demanding tasks are increasing as a result of the ongoing digital transformation. However, unlike physical work requirements, these tasks cannot be substituted by digital technologies. In particular, psychosocial demands affect everyone equally, regardless of qualification-high-skilled workers, for example, are more affected by information overload, low-skilled workers are more affected by job insecurity (Arnold et al. 2016), while substitution potential is especially high for low-skilled workers (Dengler and Matthes 2018a). Hence, no general relationship between substitution potential and psychosocial work exposure should be observable. We therefore state the following hypothesis:

H2 The potential for substitution is not associated with psychosocial work exposure.

\subsection{Digital Transformation and Gender-Segregated Work Exposure}

Men and women work in different occupations (Busch-Heinzmann 2015; Hausmann and Kleinert 2014). Whereas men are more often found in occupations with stressful environmental factors and physical strain (Beermann et al. 2008), female-dominated occupations can often be characterised as psychologically stressful work (Tophoven and Tisch 2016). Although some authors argue that women are more vulnerable to work exposure (Roxburgh 1996), others show that occupational segregation partly explains gender-segregated work exposure (Eng et al. 2011). In addition, a large proportion of women face the double burden of family and household obligations and their interaction with work exposure. In particular, women on average are more strongly influenced by the stress factor of time pressure. Aside from these differences, the relationship between work exposure, health outcomes and employment in a gender-dominated occupation (dominated by one's own or the opposite gender) 
remains uncertain. Some studies point to greater work exposure in occupations dominated by the opposite sex, while others do not find any causal relationship (Leijon et al. 2004; Mastekaasa 2005; Mastekaasa and Melsom 2014; Tophoven et al. 2015).

With regard to digital transformation, Dengler and Matthes (2016) show that men are at a higher risk of being substituted by computers or machines: the risk of substitution is approximately $21 \%$ among men, compared with only approximately $8 \%$ among women. As men are more likely to work in physically demanding occupations (Kroll et al. 2011; Beermann et al. 2008)—occupations that can be assumed to be increasingly substitutable by computers and machines - a positive relationship between substitution and physical work exposure in male-dominated occupations can be assumed. We therefore assume:

H3 The hypothesised association between substitution potential and physical work exposure should be attributed to male-dominated occupations.

With regard to gender differences, it has further been argued that new technologies might promote gender equality, because the massive distribution of mobile digital devices contributes to the normalisation of flexible work, which can favour women's ability to balance work and private life domains (Carstensen 2015, 2016). However, first empirical studies show that in the digital transformation process, psychological demands such as work intensification are higher for women than for men (Schmucker 2015). This has been attributed, among other things, to a so-called reconciling of optimisation and the dissolution of boundaries between work and private life (Lott 2016). Despite digital transformation, women are more likely to work in psychosocially demanding occupations with low computerisation and low substitution potential, such as education or health-care occupations. Hence, it can be assumed that psychosocial work exposure is high among the majority of femaledominated occupations, whether they are substitutable or not. Moreover, some studies expect a general increase in psychosocial work demands (Schütte and Köper 2013; Morschhäuser et al. 2010), which should be observed independently of substitution potential. We therefore state the following:

H4 The hypothesised association between substitution potential and psychosocial work exposure should be attributed to male- and female-dominated occupations.

\section{Data and Method}

\subsection{Data}

For our analysis, we combine different data sets aggregated at the occupational level. First, we employ large-scale administrative data from the German Federal Employment Agency; these data include the so-called IAB Employment History (BeH). The $\mathrm{BeH}$ includes information on all employees subject to social insurance contributions 
as well as minor employees ${ }^{1}$. We aggregate the information on employees for 2012 from the $\mathrm{BeH}$ at the occupational level by calculating full-time equivalents: fulltime employees get a weight of 1 , and part-time employees get a weight of 0.5 .

Second, as a measure for the degree of digital technologies, we take advantage of the substitution potential for 2012 determined by Dengler and Matthes (2018a). They use BERUFENET, the German Federal Employment Agency's occupational expert database, which contains occupational information, such as task descriptions, on all known occupations in Germany.

Third, we use the 2012 BIBB/BAuA employment survey, which collected information on 20,036 employees of at least 15 years of age and in paid employment for at least $10 \mathrm{~h}$ a week. It is the only German representative survey covering large-scale information on occupations, qualification backgrounds and job requirement levels, as well as the physical and mental strain experienced by employees (RohrbachSchmidt and Hall 2013).

We aggregate all data sets at the occupational level for the year 2012. For occupations, we consider the occupational group (three-digit level) combined with the requirement level (fifth digit) based on the 2010 German Classification of Occupations (Klassifikation der Berufe 2010).

\subsection{Variables}

Our dependent variables are the gender-specific physical and psychosocial work exposure, obtained from the 2012 BIBB/BAuA employment survey and based on an index of occupational job demands by Kroll (2011). He assigns items from the 2012 German BIBB/BAuA employment survey to five dimensions of occupational burden: 1) ergonomic stress (e.g. lifting heavy loads, working while standing), 2) environmental exposure (e.g. working in noisy, dusty or cold settings), 3) mental stress (e.g. time and performance pressure, interruptions while working), 4) social stress (e.g. no support from colleagues, no self-organisation) and 5) temporal load (e.g. shift work, working time $\geq 48 \mathrm{~h}$ per week). These dimensions are aggregated to a physical work exposure index that includes ergonomic stress and environmental exposure and a psychosocial work exposure index that includes mental stress, social stress and temporal load. Using multi-level regression models, Kroll (2011) calculates deciles for each index and for each occupation with values from 1 (the $10 \%$ of occupations with the lowest occupational work exposure) to 10 (the $10 \%$ of occupations with the highest occupational work exposure).

In additional analyses, we use employment growth between 2012 and 2016, measured by the difference between the logarithmic employment in 2012 and the logarithmic employment in 2016 based on the $\mathrm{BeH}$, as a further dependent variable.

As an indicator for the degree of digital technologies, we use the substitution potential for 2012 determined by Dengler and Matthes (2018a). It indicates the extent to which occupational tasks are substitutable by computers or computer-controlled machines. Dengler and Matthes (2018a) determine the substitution potential for occupations in Germany on the basis of the expert database BERUFENET of the

\footnotetext{
1 Minor employees are not subject to social insurance contributions and receive only $€ 450$ per month.
} 
Federal Employment Agency. BERUFENET contains up-to-date information on all occupations in Germany. Dengler and Matthes (2018a) use information on task profiles from the so-called requirement matrix, in which approximately 8,000 tasks are assigned to 4,000 occupations.

They apply the task-based approach of Autor et al. (2003) as a theoretical starting point. The task-based approach distinguishes between routine and non-routine tasks. Routine tasks (e.g. sorting or calculating) include tasks that can be performed by computers or computer-controlled machines following programmable rules, whereas non-routine tasks (e.g. managing or selling) can only be supported but not substituted by computers. Against this background, Autor et al. (2003) propose the task-biased technological change hypothesis, arguing that machines are increasingly able to perform routine tasks and will displace workers with routine jobs.

In accordance with Autor et al. (2003), Dengler and Matthes (2018a) calculate the share of routine tasks that can potentially be substituted by computers or computer-controlled machines. For each of the 8,000 tasks, three coders independently researched whether there is a computer-controlled machine or a computer algorithm that could perform this task fully automatically. This assessment is based exclusively on technical feasibility. If a task has been classified as replaceable, this does not mean that it will actually be replaced by computers or computer-controlled machines. If human work is more economical, more flexible or of better quality, or if legal or ethical obstacles prevent the use of such technologies, then replaceable tasks will not be substituted (Dengler and Matthes 2018a).

Furthermore, a variable for horizontal gender segregation in each occupation is calculated for 2012 using the $\mathrm{BeH}$ to distinguish between male-dominated occupations (with a share of women lower than or equal to $30 \%$ ), female-dominated occupations (with a share of women greater than or equal to 70\%) and gender-integrated occupations (with a share of women between 30 and 70\%). Thus far, there has been a lack of theoretically sound justifications for setting a proper threshold value (Achatz 2008). However, a number of empirical studies hint at a change in the gender designation of male-dominated occupations when the proportion of women is approximately $30 \%$ or more (e.g. Allmendinger and Hackman 1995).

Additionally, we make use of further control variables for 2012 obtained from the $\mathrm{BeH}$. At the occupational level, we calculate shares by age, qualification ${ }^{2}$, fixedterm contract, full-time employment, minor employment, foreign nationality, Eastern German residency, regional types (core cities, urbanised districts, rural districts with features of concentration, rural districts that are sparsely populated), establishment size and sectors (agriculture/manufacturing and services).

We link BeH occupational information, substitution potential and the indexes of work exposure to each other at the occupational level. In total, there are 427 occupations (occupational groups combined with the requirement level) in Germany. However, we do not consider military service or small occupations with fewer than 100 full-time-equivalent employees. As we do not have information on work expo-

\footnotetext{
2 We imputed information on qualification in accordance with Fitzenberger et al. (2005). A small number of cases with no observable information on educational background were summarised with the category "no education".
} 
sure for some occupations, we ultimately consider 361 occupations. Table 1 shows means and proportions for all variables for the total sample as well as for male-dominated, female-dominated and gender-integrated occupations separately. ${ }^{3}$ Approxi-

Table 1 Descriptive statistics. Source: own calculations, BeH (2012), BERUFENET (2012), BiBBBAuA (2012)

\begin{tabular}{|c|c|c|c|c|}
\hline Variable & Total & $\begin{array}{l}\text { Male-domi- } \\
\text { nated }\end{array}$ & $\begin{array}{l}\text { Female-domi- } \\
\text { nated }\end{array}$ & $\begin{array}{l}\text { Gender-inte- } \\
\text { grated }\end{array}$ \\
\hline \multicolumn{5}{|l|}{ Gender-integrated occupation } \\
\hline Male-dominated & 50.4 & - & - & - \\
\hline Female-dominated & 15.5 & - & - & - \\
\hline Gender-integrated & 34.1 & - & - & - \\
\hline Substitution potential & 37.3 & 46.1 & 30.7 & 27.2 \\
\hline \multicolumn{5}{|l|}{ Work exposure } \\
\hline Physical work exposure & 5.9 & 7.0 & 5.0 & 4.8 \\
\hline Psychosocial work exposure & 5.6 & 5.5 & 5.3 & 5.7 \\
\hline \multicolumn{5}{|l|}{ Age } \\
\hline 16 to $<30$ years & 17.2 & 15.1 & 20.8 & 18.6 \\
\hline$\geq 30$ to $<50$ years & 54.0 & 54.9 & 49.9 & 54.7 \\
\hline$\geq 50$ years & 28.8 & 30.0 & 29.3 & 26.7 \\
\hline \multicolumn{5}{|l|}{ Qualification } \\
\hline Low and missing education & 8.3 & 7.5 & 7.9 & 9.6 \\
\hline Medium education & 63.4 & 65.7 & 73.5 & 55.4 \\
\hline High education & 28.4 & 26.8 & 18.7 & 35.0 \\
\hline Fixed-term contract & 11.1 & 8.0 & 12.3 & 15.0 \\
\hline Full-time employment & 86.2 & 94.4 & 66.2 & 83.2 \\
\hline Minor employment & 3.3 & 1.6 & 7.0 & 4.1 \\
\hline Foreign nationality & 7.4 & 7.4 & 6.0 & 7.9 \\
\hline Eastern German residency & 19.9 & 19.3 & 20.8 & 20.5 \\
\hline \multicolumn{5}{|l|}{ Regional types } \\
\hline Core cities & 39.5 & 33.9 & 39.3 & 47.9 \\
\hline Urbanised districts & 33.6 & 36.3 & 33.1 & 29.9 \\
\hline $\begin{array}{l}\text { Rural districts with features of con- } \\
\text { centration }\end{array}$ & 14.4 & 15.9 & 14.7 & 11.9 \\
\hline Rural districts, sparsely populated & 12.5 & 13.9 & 13.0 & 10.3 \\
\hline \multicolumn{5}{|l|}{ Establishment size } \\
\hline $1-49$ & 40.0 & 38.0 & 48.6 & 39.2 \\
\hline $50-449$ & 38.8 & 39.8 & 35.2 & 38.8 \\
\hline$>500$ & 21.2 & 22.2 & 16.2 & 22.0 \\
\hline \multicolumn{5}{|l|}{ Sector } \\
\hline Agriculture and manufacturing & 34.8 & 52.2 & 7.6 & 21.3 \\
\hline Services & 65.2 & 47.8 & 92.4 & 78.7 \\
\hline Observations & 361 & 182 & 56 & 123 \\
\hline
\end{tabular}

3 Table A1 in the online appendix shows each occupation's substitution potential, physical and psychosocial work exposure and whether the occupation is male-dominated, female-dominated or gender-integrated. 
mately $50 \%$ of the occupations are male-dominated, whereas only $16 \%$ are femaledominated. The rest are gender-integrated occupations. Furthermore, the results are in line with Dengler and Matthes (2016). The average substitution potential is higher in male-dominated occupations (approximately 46\%) than in female-dominated occupations (approximately 31\%), reflecting the higher use of digital technologies in male-dominated occupations. Physical work exposure is highest in male-dominated occupations, whereas psychosocial work exposure is similar across all occupations.

\subsection{Method}

We calculate the relationship between digital transformation (measured by substitution potential) and work exposure, applying linear regression models at the occupational level. We run separate models for physical and psychosocial work exposure. To address Hypotheses 1 and 2, we run regression models for the total sample. Hypothesis 3 is addressed using a stratified analysis by male- and female-dominated occupations.

First, we analyse the bivariate relationship between substitution potential and physical as well as psychosocial work exposure. As it can be assumed that sets of sociodemographic and socioeconomic indicators at the occupational level are relevant in the relationship of interest, we add a set of controls, described above, to the models in a second step.

Finally, we run additional regression analysis on employment growth to further examine the actual relationship between substitution potential as well as work exposure and the development of occupations. We use an OLS regression weighted by the number of full-time equivalent employees to consider the size of an occupation and control for the set of control variables described in the data section.

\section{Results}

\subsection{Main Results}

As stated in the theoretical section, we expect the substitution potential to be positively associated with physical work exposure (Hypothesis 1). Accordingly, we find a positive relationship between substitution potential and physical work exposure (Table 2). However, this finding no longer holds when controlling for the full set of control variables. In particular, the share of foreign nationality, urbanised and rural districts are positively related to physical work exposure. Thus, the results are only partly in line with Hypothesis 1 . The positive relationship between substitution potential and physical work exposure seems also to result from other occupational characteristics.

Furthermore, we expect psychosocial work exposure to not be associated with substitution potential (Hypothesis 2). Our empirical findings support Hypothesis 2. Table 2 shows no significant coefficient of the substitution potential on psychosocial work exposure-neither with nor without control variables. Psychosocial work 
Table 2 Regression results of substitution potential on physical and psychosocial work exposure for the total sample. Source: own calculations, BeH (2012), BERUFENET (2012), BiBB-BAuA (2012)

\begin{tabular}{|c|c|c|c|c|}
\hline & \multicolumn{2}{|c|}{ Physical work exposure } & \multicolumn{2}{|c|}{ Psychosocial work exposure } \\
\hline & $\begin{array}{l}\text { Without con- } \\
\text { trol variables }\end{array}$ & $\begin{array}{l}\text { With control } \\
\text { variables }\end{array}$ & $\begin{array}{l}\text { Without con- } \\
\text { trol variables }\end{array}$ & $\begin{array}{l}\text { With control } \\
\text { variables }\end{array}$ \\
\hline \multirow[t]{2}{*}{$\overline{\text { Substitution potential }}$} & $2.996 * * *$ & -0.424 & 0.741 & -0.353 \\
\hline & $(0.581)$ & $(0.628)$ & $(0.599)$ & $(0.759)$ \\
\hline \multicolumn{5}{|l|}{ Age (reference: $\geq 50$ years) } \\
\hline \multirow[t]{2}{*}{16 to $<30$ years } & - & -2.986 & - & -3.464 \\
\hline & - & $(1.824)$ & - & $(2.205)$ \\
\hline \multirow[t]{2}{*}{$\geq 30$ to $<50$ years } & - & 0.560 & - & 1.077 \\
\hline & - & $(2.943)$ & - & $(3.557)$ \\
\hline \multicolumn{5}{|c|}{ Qualification (reference: low and missing education) } \\
\hline \multirow[t]{2}{*}{ Medium education } & - & 0.738 & - & -1.124 \\
\hline & - & $(3.420)$ & - & $(4.134)$ \\
\hline \multirow[t]{2}{*}{ High education } & - & -0.872 & - & -3.741 \\
\hline & - & $(3.245)$ & - & $(3.922)$ \\
\hline \multirow[t]{2}{*}{ Fixed-term contract } & - & 2.048 & - & 0.013 \\
\hline & - & (1.933) & - & $(2.336)$ \\
\hline \multirow[t]{2}{*}{ Full-time employment } & - & 2.227 & - & 0.981 \\
\hline & - & $(1.717)$ & - & $(2.075)$ \\
\hline \multirow[t]{2}{*}{ Minor employment } & - & 0.921 & - & 5.236 \\
\hline & - & $(4.107)$ & - & $(4.964)$ \\
\hline \multirow[t]{2}{*}{ Foreign nationality } & - & $11.947 * * *$ & - & $8.350^{*}$ \\
\hline & - & $(3.568)$ & - & $(4.312)$ \\
\hline \multirow{2}{*}{$\begin{array}{l}\text { Eastern German } \\
\text { residency }\end{array}$} & - & 1.154 & - & 3.525 \\
\hline & - & $(2.258)$ & - & $(2.729)$ \\
\hline \multicolumn{5}{|c|}{ Regional types (reference: core cities) } \\
\hline \multirow[t]{2}{*}{ Urbanised districts } & - & $4.357 * *$ & - & 0.148 \\
\hline & - & $(2.075)$ & - & $(2.508)$ \\
\hline \multirow{2}{*}{$\begin{array}{l}\text { Rural districts with } \\
\text { features of concentration }\end{array}$} & - & $8.805^{* *}$ & - & 5.891 \\
\hline & - & $(4.069)$ & - & $(4.918)$ \\
\hline \multirow{2}{*}{$\begin{array}{l}\text { Rural districts, sparsely } \\
\text { populated }\end{array}$} & - & $10.752 * * *$ & - & -2.487 \\
\hline & - & $(3.453)$ & - & $(4.174)$ \\
\hline \multicolumn{5}{|c|}{ Establishment size (reference: 1-49) } \\
\hline \multirow[t]{2}{*}{$50-449$} & - & -0.633 & - & $5.373 * * *$ \\
\hline & - & $(1.041)$ & - & $(1.258)$ \\
\hline \multirow[t]{2}{*}{$>500$} & - & 0.713 & - & $4.103 * * *$ \\
\hline & - & $(0.976)$ & - & $(1.179)$ \\
\hline
\end{tabular}


Table 2 (Continued)

\begin{tabular}{|c|c|c|c|c|}
\hline & \multicolumn{2}{|c|}{ Physical work exposure } & \multicolumn{2}{|c|}{ Psychosocial work exposure } \\
\hline & $\begin{array}{l}\text { Without con- } \\
\text { trol variables }\end{array}$ & $\begin{array}{l}\text { With control } \\
\text { variables }\end{array}$ & $\begin{array}{l}\text { Without con- } \\
\text { trol variables }\end{array}$ & $\begin{array}{l}\text { With control } \\
\text { variables }\end{array}$ \\
\hline \multicolumn{5}{|c|}{ Sector (reference: agriculture and manufacturing) } \\
\hline \multirow[t]{2}{*}{ Services } & - & -1.084 & - & 1.189 \\
\hline & - & $(0.702)$ & - & $(0.848)$ \\
\hline \multirow[t]{2}{*}{ Constant } & $4.803 * * *$ & -0.495 & $5.281 * * *$ & 0.823 \\
\hline & $(0.263)$ & $(4.559)$ & $(0.271)$ & $(5.510)$ \\
\hline Observations & 361 & 361 & 361 & 361 \\
\hline Adjusted $R^{2}$ & 0.0664 & 0.4414 & 0.0015 & 0.1803 \\
\hline
\end{tabular}

Example of interpretation: an increase in the substitution potential by 1 percentage point is related to a slight decrease in physical work exposure by 0.03 units (row 1 )

Standard errors in parentheses

$* * * p<0.01, * * p<0.05, * p<0.1$

exposure rather seems to relate to establishment size: the share of medium or large establishments is positively associated with psychosocial work exposure.

Regarding Hypotheses 3 and 4, we expect that substitution potential is positively associated with physical work exposure because of the substitution potential in maledominated occupations, whereas substitution potential is not associated with psychosocial work exposure in male- and female-dominated occupations. The results for male-dominated occupations imply a positive relationship between substitution potential and physical work exposure-both in the model without control variables and in the model with the full set of control variables (Table 3). However, the relationship seems to be reversed in female-dominated occupations (Table 4). Furthermore, bivariate regression results indicate that substitution potential is positively related to psychosocial work exposure in male-dominated occupations (Table 3) and negatively related in female-dominated occupations (Table 4). After controlling for a set of further occupational characteristics, we find no relationship between substitution potential and psychosocial work exposure for either male- or femaledominated occupations. Thus, we find empirical evidence supporting Hypothesis 4, as substitution potential is not associated with psychosocial work exposure in maleand female-dominated occupations. ${ }^{4}$

Regarding the results of the control variables, we find that the shares of fixedterm contracts and full-time employment are positively associated with physical work exposure in male-dominated occupations, whereas the shares of young-aged employees or large establishment size are negatively related to physical work exposure (Table 3). In particular, the share of medium or large establishment size is positively related to psychosocial work exposure in male-dominated occupations (Table 3). For female-dominated occupations, the control variables are mostly not significant (Table 4). However, one noteworthy finding is that the service sector share is positively associated with psychosocial work exposure. This might result

\footnotetext{
${ }^{4}$ Furthermore, we consider gender-integrated occupations. Results can be found in Table A2 in the online appendix.
} 
Table 3 Regression results of substitution potential on physical and psychosocial work exposure for male-dominated occupations. Source: own calculations, BeH (2012), BERUFENET (2012), BiBB-BAuA (2012)

\begin{tabular}{|c|c|c|c|c|}
\hline & \multicolumn{2}{|c|}{ Physical work exposure } & \multicolumn{2}{|c|}{ Psychosocial work exposure } \\
\hline & $\begin{array}{l}\text { Without con- } \\
\text { trol variables }\end{array}$ & $\begin{array}{l}\text { With control } \\
\text { variables }\end{array}$ & $\begin{array}{l}\text { Without con- } \\
\text { trol variables }\end{array}$ & $\begin{array}{l}\text { With control } \\
\text { variables }\end{array}$ \\
\hline Substitution potential & $\begin{array}{l}3.365 * * * \\
(0.809)\end{array}$ & $\begin{array}{l}1.989 * * \\
(0.873)\end{array}$ & $\begin{array}{l}3.286 * * * \\
(0.828)\end{array}$ & $\begin{array}{l}1.214 \\
(0.980)\end{array}$ \\
\hline \multicolumn{5}{|l|}{ Age (reference: $\geq 50$ years) } \\
\hline 16 to $<30$ years & $\begin{array}{l}- \\
-\end{array}$ & $\begin{array}{l}-7.140 * * \\
(2.899)\end{array}$ & $\begin{array}{l}- \\
-\end{array}$ & $\begin{array}{l}-6.951 * * \\
(3.255)\end{array}$ \\
\hline$\geq 30$ to $<50$ years & $\begin{array}{l}- \\
-\end{array}$ & $\begin{array}{l}-1.048 \\
(4.674)\end{array}$ & - & $\begin{array}{l}0.002 \\
(5.247)\end{array}$ \\
\hline \multicolumn{5}{|c|}{ Qualification (reference: low and missing education) } \\
\hline Medium education & $\begin{array}{l}- \\
-\end{array}$ & $\begin{array}{l}-4.406 \\
(5.925)\end{array}$ & - & $\begin{array}{l}3.015 \\
(6.651)\end{array}$ \\
\hline High education & $\begin{array}{l}- \\
-\end{array}$ & $\begin{array}{l}-5.498 \\
(5.614)\end{array}$ & - & $\begin{array}{l}-0.343 \\
(6.302)\end{array}$ \\
\hline Fixed-term contract & $\begin{array}{l}- \\
-\end{array}$ & $\begin{array}{l}9.806^{* *} \\
(4.488)\end{array}$ & - & $\begin{array}{l}-2.455 \\
(5.039)\end{array}$ \\
\hline Full-time employment & $\begin{array}{l}- \\
-\end{array}$ & $\begin{array}{l}15.516^{*} \\
(8.311)\end{array}$ & - & $\begin{array}{l}-2.052 \\
(9.330)\end{array}$ \\
\hline Minor employment & $\begin{array}{l}- \\
-\end{array}$ & $\begin{array}{l}11.936 \\
(14.542)\end{array}$ & - & $\begin{array}{l}10.518 \\
(16.325)\end{array}$ \\
\hline Foreign nationality & $\begin{array}{l}- \\
-\end{array}$ & $\begin{array}{l}-0.203 \\
(6.310)\end{array}$ & - & $\begin{array}{l}12.658^{*} \\
(7.084)\end{array}$ \\
\hline $\begin{array}{l}\text { Eastern German } \\
\text { residency }\end{array}$ & $\begin{array}{l}- \\
-\end{array}$ & $\begin{array}{l}-1.503 \\
(3.744)\end{array}$ & - & $\begin{array}{l}3.340 \\
(4.204)\end{array}$ \\
\hline Regional types (reference. & re cities) & & & \\
\hline Urbanised districts & $\begin{array}{l}- \\
-\end{array}$ & $\begin{array}{l}-1.266 \\
(2.771)\end{array}$ & - & $\begin{array}{l}-2.716 \\
(3.111)\end{array}$ \\
\hline $\begin{array}{l}\text { Rural districts with } \\
\text { features of concentration }\end{array}$ & $\begin{array}{l}- \\
-\end{array}$ & $\begin{array}{l}7.115 \\
(5.459)\end{array}$ & - & $\begin{array}{l}2.004 \\
(6.129)\end{array}$ \\
\hline $\begin{array}{l}\text { Rural districts, sparsely } \\
\text { populated }\end{array}$ & $\begin{array}{l}- \\
-\end{array}$ & $\begin{array}{l}8.239 * \\
(4.492)\end{array}$ & - & $\begin{array}{l}-3.873 \\
(5.043)\end{array}$ \\
\hline Establishment size (refere & $(1-49)$ & & & \\
\hline $50-449$ & $\begin{array}{l}- \\
-\end{array}$ & $\begin{array}{l}-2.662 \\
(1.622)\end{array}$ & $\begin{array}{l}- \\
-\end{array}$ & $\begin{array}{l}7.542 * * * \\
(1.821)\end{array}$ \\
\hline$>500$ & - & $\begin{array}{l}-2.585^{*} \\
(1.547)\end{array}$ & - & $\begin{array}{l}4.619 * * * \\
(1.737)\end{array}$ \\
\hline
\end{tabular}


Table 3 (Continued)

\begin{tabular}{|c|c|c|c|c|}
\hline & \multicolumn{2}{|c|}{ Physical work exposure } & \multicolumn{2}{|c|}{ Psychosocial work exposure } \\
\hline & $\begin{array}{l}\text { Without con- } \\
\text { trol variables }\end{array}$ & $\begin{array}{l}\text { With control } \\
\text { variables }\end{array}$ & $\begin{array}{l}\text { Without con- } \\
\text { trol variables }\end{array}$ & $\begin{array}{l}\text { With control } \\
\text { variables }\end{array}$ \\
\hline \multicolumn{5}{|c|}{ Sector (reference: agriculture and manufacturing) } \\
\hline \multirow[t]{2}{*}{ Services } & - & -1.132 & - & -0.198 \\
\hline & - & $(0.939)$ & - & $(1.054)$ \\
\hline \multirow[t]{2}{*}{ Constant } & $5.410 * * *$ & -2.902 & $4.018 * * *$ & 1.784 \\
\hline & $(0.424)$ & $(10.698)$ & $(0.434)$ & $(12.010)$ \\
\hline Observations & 182 & 182 & 182 & 182 \\
\hline Adjusted $R^{2}$ & 0.0827 & 0.3997 & 0.0754 & 0.2727 \\
\hline
\end{tabular}

Example of interpretation: an increase in the substitution potential by 1 percentage point is related to an increase in physical work exposure by 0.03 or 0.02 units (rows 1 and 2)

Standard errors in parentheses

$* * * p<0.01, * * p<0.05, * p<0.1$

from comparatively high temporal workloads in the service sector, such as weekend work or shift work.

In summary, empirical evidence is mostly in line with our hypotheses. The results imply that digital technologies may be associated with improved working conditions in male-dominated, but not in female-dominated occupations: male-dominated occupations show a positive relationship between substitution potential and physical work exposure. Many tasks within these occupations may increasingly be substitutable by computers and, therefore, these occupations could become less demanding.

\subsection{Additional Analyses}

As we do not know the extent to which substitution potential and work exposure are related to occupation-specific employment growth, we carry out additional analyses.

In Model 1, we regress the 2012 substitution potential on the employment growth between 2012 and 2016 to approximate the extent to which substitution potential is actually transformed into human replacement. The substitution potential only refers to technical feasibility, meaning it measures the theoretically possible substitution of tasks by computers or computer-controlled machines. If a task is classified as replaceable, this does not mean that it will actually be replaced in the next few years. Where human labour is regarded as more economical, flexible or of better quality or where legal or ethical barriers prevent the use of new technologies, a task is not likely to be replaced. The results imply that substitution potential is negatively associated with employment growth (Table 5, Model 1).

In Model 2, we regress physical and psychosocial work exposure on employment growth to examine whether more highly exposed occupations are declining in importance. In Model 3, we include substitution potential and physical as well as psychosocial work exposure as additional control variables. The results imply that after controlling for substitution potential, occupations with physical work exposure were more likely to downsize between 2012 and 2016 (Table 5, Model 3). 
Table 4 Regression results of substitution potential on physical and psychosocial work exposure for female-dominated occupations. Source: own calculations, BeH (2012), BERUFENET (2012), BiBBBAuA (2012)

\begin{tabular}{|c|c|c|c|c|}
\hline & \multicolumn{2}{|c|}{ Physical work exposure } & \multicolumn{2}{|c|}{ Psychosocial work exposure } \\
\hline & $\begin{array}{l}\text { Without con- } \\
\text { trol variables }\end{array}$ & $\begin{array}{l}\text { With control } \\
\text { variables }\end{array}$ & $\begin{array}{l}\text { Without con- } \\
\text { trol variables }\end{array}$ & $\begin{array}{l}\text { With control } \\
\text { variables }\end{array}$ \\
\hline$\overline{\text { Substitution potential }}$ & $\begin{array}{l}-5.833^{* * *} \\
(1.168)\end{array}$ & $\begin{array}{l}-4.942 * * * \\
(1.428)\end{array}$ & $\begin{array}{l}-3.975 * * \\
(1.694)\end{array}$ & $\begin{array}{l}0.208 \\
(2.533)\end{array}$ \\
\hline \multicolumn{5}{|l|}{ Age (reference: $\geq 50$ years) } \\
\hline 16 to $<30$ years & $\begin{array}{l}- \\
-\end{array}$ & $\begin{array}{l}-1.541 \\
(4.428)\end{array}$ & $\begin{array}{l}- \\
-\end{array}$ & $\begin{array}{l}-1.836 \\
(7.851)\end{array}$ \\
\hline$\geq 30$ to $<50$ years & $\begin{array}{l}- \\
-\end{array}$ & $\begin{array}{l}-1.323 \\
(7.105)\end{array}$ & - & $\begin{array}{l}16.502 \\
(12.599)\end{array}$ \\
\hline \multicolumn{5}{|c|}{ Qualification (reference: low and missing education) } \\
\hline Medium education & $\begin{array}{l}- \\
-\end{array}$ & $\begin{array}{l}4.460 \\
(11.515)\end{array}$ & - & $\begin{array}{l}-15.131 \\
(20.418)\end{array}$ \\
\hline High education & - & $\begin{array}{l}-0.197 \\
(11.372)\end{array}$ & - & $\begin{array}{l}-19.263 \\
(20.165)\end{array}$ \\
\hline Fixed-term contract & - & $\begin{array}{l}-5.512 \\
(6.460)\end{array}$ & - & $\begin{array}{l}3.025 \\
(11.456)\end{array}$ \\
\hline Full-time employment & - & $\begin{array}{l}-2.028 \\
(3.928)\end{array}$ & - & $\begin{array}{l}2.397 \\
(6.965)\end{array}$ \\
\hline Minor employment & - & $\begin{array}{l}1.287 \\
(5.957)\end{array}$ & $\begin{array}{l}- \\
-\end{array}$ & $\begin{array}{l}0.692 \\
(10.563)\end{array}$ \\
\hline Foreign nationality & - & $\begin{array}{l}9.883 \\
(10.797)\end{array}$ & - & $\begin{array}{l}-7.586 \\
(19.146)\end{array}$ \\
\hline $\begin{array}{l}\text { Eastern German } \\
\text { residency }\end{array}$ & - & $\begin{array}{l}5.257 \\
(6.106)\end{array}$ & $\begin{array}{l}- \\
-\end{array}$ & $\begin{array}{l}1.476 \\
(10.827)\end{array}$ \\
\hline Regional types (reference. & re cities) & & & \\
\hline Urbanised districts & - & $\begin{array}{l}6.081 \\
(12.627)\end{array}$ & - & $\begin{array}{l}-14.395 \\
(22.390)\end{array}$ \\
\hline $\begin{array}{l}\text { Rural districts with } \\
\text { features of concentration }\end{array}$ & - & $\begin{array}{l}32.868 \\
(26.651)\end{array}$ & $\begin{array}{l}- \\
-\end{array}$ & $\begin{array}{l}91.102 * \\
(47.259)\end{array}$ \\
\hline $\begin{array}{l}\text { Rural districts, sparsely } \\
\text { populated }\end{array}$ & $\begin{array}{l}- \\
-\end{array}$ & $\begin{array}{l}-11.596 \\
(21.442)\end{array}$ & - & $\begin{array}{l}-44.649 \\
(38.021)\end{array}$ \\
\hline Establishment size (refere & $1-49)$ & & & \\
\hline $50-449$ & $\begin{array}{l}- \\
-\end{array}$ & $\begin{array}{l}-0.528 \\
(2.748)\end{array}$ & - & $\begin{array}{l}3.613 \\
(4.873)\end{array}$ \\
\hline$>500$ & - & $\begin{array}{l}4.473 * * \\
(1.869)\end{array}$ & $\begin{array}{l}- \\
-\end{array}$ & $\begin{array}{l}3.782 \\
(3.314)\end{array}$ \\
\hline
\end{tabular}


Table 4 (Continued)

\begin{tabular}{|c|c|c|c|c|}
\hline & \multicolumn{2}{|c|}{ Physical work exposure } & \multicolumn{2}{|c|}{ Psychosocial work exposure } \\
\hline & $\begin{array}{l}\text { Without con- } \\
\text { trol variables }\end{array}$ & $\begin{array}{l}\text { With control } \\
\text { variables }\end{array}$ & $\begin{array}{l}\text { Without con- } \\
\text { trol variables }\end{array}$ & $\begin{array}{l}\text { With control } \\
\text { variables }\end{array}$ \\
\hline \multicolumn{5}{|c|}{ Sector (reference: agriculture and manufacturing) } \\
\hline \multirow[t]{2}{*}{ Services } & - & 2.709 & - & $13.275^{* * *}$ \\
\hline & - & $(2.516)$ & - & $(4.462)$ \\
\hline \multirow[t]{2}{*}{ Constant } & $6.807 * * *$ & -3.852 & $6.469 * * *$ & -6.783 \\
\hline & $(0.449)$ & $(12.599)$ & $(0.651)$ & $(22.340)$ \\
\hline Observations & 56 & 56 & 56 & 56 \\
\hline Adjusted $R^{2}$ & 0.3034 & 0.6117 & 0.0757 & 0.2305 \\
\hline
\end{tabular}

Example of interpretation: an increase in the substitution potential by 1 percentage point is associated with a decrease in physical work exposure by approximately 0.05 units (row 1 and row 2)

Standard errors in parentheses

$* * * p<0.01, * * p<0.05, * p<0.1$

In a fourth model, interaction terms between substitution potential and physical as well as psychosocial work exposure were added. We expect occupations with high physical work exposure and substitution potential to shrink over time. Furthermore, as we find no relationship between substitution potential and psychosocial work exposure, there should be no relationship between the interaction term of substitution potential and psychosocial work exposure and employment growth.

Regarding the results of the interaction terms (Table 5, Model 4), we do not find evidence that substitution potential and physical work exposure are related to a decrease in employment growth. Instead, substitution potential and physical work exposure are independently associated with declining employment growth. Furthermore, we find that substitution potential and psychosocial work exposure are negatively related to employment growth. However, stratified analyses indicate that this relationship can only be found in male-dominated occupations (Table 6 , Model 4). ${ }^{5}$ The stratified analyses further reveal the results for male-dominated occupations to be very similar to the results for the total sample. Regarding the results for female-dominated occupations, we find no relationship between substitution potential, physical or psychosocial work exposure and employment growth (Table 7).

As regards the control variables, we find the following results. The shares of young-aged employees, urbanised districts, rural districts (sparsely populated) and medium establishments are positively associated with employment growth. However, for male- and female-dominated occupations, different occupational characteristics play a role in terms of employment growth. For male-dominated occupations, the shares of young-aged employees, medium or high education, foreign nationality and medium establishments are mostly positively related to employment growth. For female-dominated occupations, however, the shares of fixed-term contracts, fulltime employment, urbanised districts, large establishments and the service sector play a role in employment growth.

\footnotetext{
5 Furthermore, we consider gender-integrated occupations. Results can be found in Table A3 in the online appendix.
} 
Table 5 Relationship between work exposure and substitution potential in 2012 and employment growth between 2012 and 2016 for the total sample. Source: own calculations, BeH (2012), BERUFENET (2012), BiBB-BAuA (2012)

\begin{tabular}{|c|c|c|c|c|}
\hline & $\begin{array}{l}\text { Model } 1 \\
\text { (Substitution } \\
\text { potential) }\end{array}$ & $\begin{array}{l}\text { Model } 2 \\
\text { (Work expo- } \\
\text { sure) }\end{array}$ & $\begin{array}{l}\text { Model } 3 \\
\text { (Substitution } \\
\text { potential+ } \\
\text { work expo- } \\
\text { sure) }\end{array}$ & $\begin{array}{l}\text { Model } 4 \\
\text { (Interaction } \\
\text { term) }\end{array}$ \\
\hline$\overline{\text { Substitution potential }}$ & $\begin{array}{l}-0.124 * * * \\
(0.021)\end{array}$ & $\begin{array}{l}- \\
-\end{array}$ & $\begin{array}{l}-0.137 * * * \\
(0.022)\end{array}$ & $\begin{array}{l}-0.120 * * * \\
(0.042)\end{array}$ \\
\hline \multicolumn{5}{|l|}{ Work exposure } \\
\hline Physical work exposure & - & $\begin{array}{l}-0.001 \\
(0.002)\end{array}$ & $\begin{array}{l}-0.005^{* *} \\
(0.002)\end{array}$ & $\begin{array}{l}-0.008^{* *} \\
(0.004)\end{array}$ \\
\hline $\begin{array}{l}\text { Psychosocial work } \\
\text { exposure }\end{array}$ & - & $\begin{array}{l}0.001 \\
(0.002)\end{array}$ & $\begin{array}{l}0.002 \\
(0.002)\end{array}$ & $\begin{array}{l}0.007 * * \\
(0.003)\end{array}$ \\
\hline \multicolumn{5}{|l|}{ Interaction term } \\
\hline $\begin{array}{l}\text { Substitution potential and } \\
\text { physical work exposure }\end{array}$ & - & - & $\begin{array}{l}- \\
-\end{array}$ & $\begin{array}{l}0.010 \\
(0.008)\end{array}$ \\
\hline $\begin{array}{l}\text { Substitution potential and } \\
\text { psychosocial work } \\
\text { exposure }\end{array}$ & - & - & - & $\begin{array}{l}-0.014^{*} \\
(0.007)\end{array}$ \\
\hline \multicolumn{5}{|l|}{ Age (reference: $\geq 50$ years) } \\
\hline 16 to $<30$ years & $\begin{array}{l}0.322 * * * \\
(0.060)\end{array}$ & $\begin{array}{l}0.315^{* * *} \\
(0.063)\end{array}$ & $\begin{array}{l}0.326^{* * * *} \\
(0.060)\end{array}$ & $\begin{array}{l}0.346 * * * \\
(0.061)\end{array}$ \\
\hline$\geq 30$ to $<50$ years & $\begin{array}{l}0.131 \\
(0.132)\end{array}$ & $\begin{array}{l}0.408 * * * \\
(0.131)\end{array}$ & $\begin{array}{l}0.113 \\
(0.133)\end{array}$ & $\begin{array}{l}0.128 \\
(0.133)\end{array}$ \\
\hline \multicolumn{5}{|c|}{ Qualification (reference: low and missing education) } \\
\hline Medium education & $\begin{array}{l}-0.048 \\
(0.155)\end{array}$ & $\begin{array}{l}0.101 \\
(0.162)\end{array}$ & $\begin{array}{l}-0.081 \\
(0.156)\end{array}$ & $\begin{array}{l}-0.113 \\
(0.158)\end{array}$ \\
\hline High education & $\begin{array}{l}0.068 \\
(0.150)\end{array}$ & $\begin{array}{l}0.231 \\
(0.155)\end{array}$ & $\begin{array}{l}0.028 \\
(0.151)\end{array}$ & $\begin{array}{l}-0.003 \\
(0.152)\end{array}$ \\
\hline Fixed-term contract & $\begin{array}{l}-0.011 \\
(0.070)\end{array}$ & $\begin{array}{l}0.050 \\
(0.073)\end{array}$ & $\begin{array}{l}-0.012 \\
(0.070)\end{array}$ & $\begin{array}{l}-0.031 \\
(0.071)\end{array}$ \\
\hline Full-time employment & $\begin{array}{l}0.015 \\
(0.042)\end{array}$ & $\begin{array}{l}-0.023 \\
(0.043)\end{array}$ & $\begin{array}{l}0.019 \\
(0.042)\end{array}$ & $\begin{array}{l}0.009 \\
(0.043)\end{array}$ \\
\hline Minor employment & $\begin{array}{l}0.027 \\
(0.118)\end{array}$ & $\begin{array}{l}0.096 \\
(0.126)\end{array}$ & $\begin{array}{l}-0.003 \\
(0.121)\end{array}$ & $\begin{array}{l}-0.022 \\
(0.121)\end{array}$ \\
\hline Foreign nationality & $\begin{array}{c}-0.038 \\
(0.172)\end{array}$ & $\begin{array}{l}0.134 \\
(0.185)\end{array}$ & $\begin{array}{l}-0.009 \\
(0.176)\end{array}$ & $\begin{array}{l}-0.028 \\
(0.178)\end{array}$ \\
\hline $\begin{array}{l}\text { Eastern German } \\
\text { residency }\end{array}$ & $\begin{array}{l}0.007 \\
(0.112)\end{array}$ & $\begin{array}{l}0.142 \\
(0.118)\end{array}$ & $\begin{array}{l}0.005 \\
(0.114)\end{array}$ & $\begin{array}{l}0.005 \\
(0.114)\end{array}$ \\
\hline
\end{tabular}


Table 5 (Continued)

\begin{tabular}{|c|c|c|c|c|}
\hline & $\begin{array}{l}\text { Model } 1 \\
\text { (Substitution } \\
\text { potential) }\end{array}$ & $\begin{array}{l}\text { Model } 2 \\
\text { (Work expo- } \\
\text { sure) }\end{array}$ & $\begin{array}{l}\text { Model } 3 \\
\text { (Substitution } \\
\text { potential+ } \\
\text { work expo- } \\
\text { sure) }\end{array}$ & $\begin{array}{l}\text { Model } 4 \\
\text { (Interaction } \\
\text { term) }\end{array}$ \\
\hline \multicolumn{5}{|c|}{ Regional types (reference: core cities) } \\
\hline Urbanised districts & $\begin{array}{l}0.327 * * * \\
(0.107)\end{array}$ & $\begin{array}{l}0.323 * * * \\
(0.114)\end{array}$ & $\begin{array}{l}0.350 * * * \\
(0.108)\end{array}$ & $\begin{array}{l}0.360 * * * \\
(0.108)\end{array}$ \\
\hline $\begin{array}{l}\text { Rural districts with } \\
\text { features of concentration }\end{array}$ & $\begin{array}{l}-0.529 * * \\
(0.240)\end{array}$ & $\begin{array}{l}-0.530 * * \\
(0.257)\end{array}$ & $\begin{array}{l}-0.473 * \\
(0.244)\end{array}$ & $\begin{array}{l}-0.456^{*} \\
(0.245)\end{array}$ \\
\hline $\begin{array}{l}\text { Rural districts, sparsely } \\
\text { populated }\end{array}$ & $\begin{array}{l}0.546 * * * \\
(0.205)\end{array}$ & $\begin{array}{l}0.681 * * * \\
(0.218)\end{array}$ & $\begin{array}{l}0.604 * * * \\
(0.207)\end{array}$ & $\begin{array}{l}0.618 * * * \\
(0.208)\end{array}$ \\
\hline \multicolumn{5}{|c|}{ Establishment size (reference: $1-49$ ) } \\
\hline $50-449$ & $\begin{array}{l}0.187 * * * \\
(0.038)\end{array}$ & $\begin{array}{l}0.197 * * * \\
(0.042)\end{array}$ & $\begin{array}{l}0.170 * * * \\
(0.040)\end{array}$ & $\begin{array}{l}0.172 * * * \\
(0.040)\end{array}$ \\
\hline$>500$ & $\begin{array}{l}0.027 \\
(0.033)\end{array}$ & $\begin{array}{l}-0.001 \\
(0.035)\end{array}$ & $\begin{array}{l}0.032 \\
(0.034)\end{array}$ & $\begin{array}{l}0.033 \\
(0.034)\end{array}$ \\
\hline \multicolumn{5}{|c|}{ Sector (reference: agriculture and manufacturing) } \\
\hline Services & $\begin{array}{l}0.021 \\
(0.022)\end{array}$ & $\begin{array}{l}0.063 * * * \\
(0.022)\end{array}$ & $\begin{array}{l}0.012 \\
(0.023)\end{array}$ & $\begin{array}{l}0.007 \\
(0.023)\end{array}$ \\
\hline Constant & $\begin{array}{l}-0.216 \\
(0.201)\end{array}$ & $\begin{array}{l}-0.611 * * * \\
(0.205)\end{array}$ & $\begin{array}{l}-0.170 \\
(0.206)\end{array}$ & $\begin{array}{l}-0.151 \\
(0.206)\end{array}$ \\
\hline Observations & 361 & 361 & 361 & 361 \\
\hline Adjusted $R^{2}$ & 0.3407 & 0.2714 & 0.3447 & 0.348 \\
\hline
\end{tabular}

Example of interpretation: an increase in the substitution potential of 1 percentage point is related to a decrease in employment growth by $0.12 \%$ (row 1). An increase in physical work exposure by 1 unit is associated with a decrease in employment growth by $0.5 \%$ (row 3 )

Standard errors in parentheses

$* * * p<0.01, * * p<0.05, * p<0.1$

In summary, we find a negative relationship between substitution potential and employment growth; this relationship can also be found for physical work exposure, but not for substitution potential and physical work exposure. Hence, physically demanding jobs seem to downsize, but also independently of digital transformation. These results hold for the total sample and male-dominated occupations, but not for female-dominated occupations.

\section{Summary and Conclusions}

Digital transformation may have a large impact on the labour market. In recent debates, the notion that machines could take people's jobs is a major concern. In this context, little attention has been paid to the impact of digital transformation on aspects of work quality. However, some studies indicate that digital transformation could relieve employees of physically demanding or monotonous tasks (Arnold et al. 2016). Psychosocial tasks, in contrast, are not likely to be substituted by 
Table 6 Relationship between work exposure and substitution potential in 2012 and employment growth between 2012 and 2016 for male-dominated occupations. Source: own calculations, BeH (2012), BERUFENET (2012), BiBB-BAuA (2012)

\begin{tabular}{|c|c|c|c|c|}
\hline & $\begin{array}{l}\text { Model } 1 \\
\text { (Substitution } \\
\text { potential) }\end{array}$ & $\begin{array}{l}\text { Model } 2 \\
\text { (Work expo- } \\
\text { sure) }\end{array}$ & $\begin{array}{l}\text { Model } 3 \\
\text { (Substitution } \\
\text { poten- } \\
\text { tial + work } \\
\text { exposure) }\end{array}$ & $\begin{array}{l}\text { Model } 4 \\
\text { (Interaction } \\
\text { term) }\end{array}$ \\
\hline Substitution potential & $\begin{array}{l}-0.087 * * * \\
(0.029)\end{array}$ & - & $\begin{array}{l}-0.082 * * * \\
(0.029)\end{array}$ & $\begin{array}{l}0.057 \\
(0.067)\end{array}$ \\
\hline \multicolumn{5}{|l|}{ Work exposure } \\
\hline Physical work exposure & - & $\begin{array}{l}-0.009 * * \\
(0.003)\end{array}$ & $\begin{array}{l}-0.008 * * \\
(0.003)\end{array}$ & $\begin{array}{l}-0.009^{*} \\
(0.005)\end{array}$ \\
\hline $\begin{array}{l}\text { Psychosocial work } \\
\text { exposure }\end{array}$ & - & $\begin{array}{l}-0.001 \\
(0.003)\end{array}$ & $\begin{array}{l}-0.001 \\
(0.003)\end{array}$ & $\begin{array}{l}0.013 * * \\
(0.005)\end{array}$ \\
\hline \multicolumn{5}{|l|}{ Interaction term } \\
\hline $\begin{array}{l}\text { Substitution potential and } \\
\text { physical work exposure }\end{array}$ & - & - & - & $\begin{array}{l}0.005 \\
(0.010)\end{array}$ \\
\hline $\begin{array}{l}\text { Substitution potential and } \\
\text { psychosocial work } \\
\text { exposure }\end{array}$ & - & - & - & $\begin{array}{l}-0.030 * * * \\
(0.010)\end{array}$ \\
\hline \multicolumn{5}{|l|}{ Age (reference: $\geq 50$ years) } \\
\hline 16 to $<30$ years & $\begin{array}{l}0.413 * * * \\
(0.108)\end{array}$ & $\begin{array}{l}0.312 * * * \\
(0.106)\end{array}$ & $\begin{array}{l}0.398 * * * \\
(0.108)\end{array}$ & $\begin{array}{l}0.457 * * * \\
(0.108)\end{array}$ \\
\hline$\geq 30$ to $<50$ years & $\begin{array}{l}0.116 \\
(0.198)\end{array}$ & $\begin{array}{l}0.303 \\
(0.189)\end{array}$ & $\begin{array}{l}0.132 \\
(0.195)\end{array}$ & $\begin{array}{l}0.246 \\
(0.193)\end{array}$ \\
\hline \multicolumn{5}{|c|}{ Qualification (reference: low and missing education) } \\
\hline Medium education & $\begin{array}{l}0.533 * * \\
(0.235)\end{array}$ & $\begin{array}{l}0.450 * \\
(0.244)\end{array}$ & $\begin{array}{l}0.426^{*} \\
(0.239)\end{array}$ & $\begin{array}{l}0.371 \\
(0.234)\end{array}$ \\
\hline High education & $\begin{array}{l}0.616^{* * * *} \\
(0.226)\end{array}$ & $\begin{array}{l}0.504 * * \\
(0.236)\end{array}$ & $\begin{array}{l}0.484 * * \\
(0.231)\end{array}$ & $\begin{array}{l}0.444 * \\
(0.226)\end{array}$ \\
\hline Fixed-term contract & $\begin{array}{l}-0.425^{* *} \\
(0.201)\end{array}$ & $\begin{array}{l}-0.276 \\
(0.200)\end{array}$ & $\begin{array}{l}-0.379 * \\
(0.199)\end{array}$ & $\begin{array}{l}-0.481^{* *} \\
(0.197)\end{array}$ \\
\hline Full-time employment & $\begin{array}{l}-0.923 * * * \\
(0.327)\end{array}$ & $\begin{array}{l}-1.140 * * * \\
(0.325)\end{array}$ & $\begin{array}{l}-0.981 * * * \\
(0.323)\end{array}$ & $\begin{array}{l}-1.048^{* * * *} \\
(0.319)\end{array}$ \\
\hline Minor employment & $\begin{array}{l}-0.707 \\
(0.572)\end{array}$ & $\begin{array}{l}-1.108 * \\
(0.573)\end{array}$ & $\begin{array}{l}-0.877 \\
(0.568)\end{array}$ & $\begin{array}{l}-0.951^{*} \\
(0.554)\end{array}$ \\
\hline Foreign nationality & $\begin{array}{l}0.748 * * * \\
(0.271)\end{array}$ & $\begin{array}{l}0.682 * * \\
(0.286)\end{array}$ & $\begin{array}{l}0.699 * * \\
(0.281)\end{array}$ & $\begin{array}{l}0.782 * * * \\
(0.275)\end{array}$ \\
\hline $\begin{array}{l}\text { Eastern German } \\
\text { residency }\end{array}$ & $\begin{array}{l}0.078 \\
(0.201)\end{array}$ & $\begin{array}{l}0.137 \\
(0.202)\end{array}$ & $\begin{array}{l}0.111 \\
(0.198)\end{array}$ & $\begin{array}{l}0.127 \\
(0.193)\end{array}$ \\
\hline
\end{tabular}


Table 6 (Continued)

\begin{tabular}{|c|c|c|c|c|}
\hline & $\begin{array}{l}\text { Model } 1 \\
\text { (Substitution } \\
\text { potential) }\end{array}$ & $\begin{array}{l}\text { Model } 2 \\
\text { (Work expo- } \\
\text { sure) }\end{array}$ & $\begin{array}{l}\text { Model } 3 \\
\text { (Substitution } \\
\text { poten- } \\
\text { tial+ work } \\
\text { exposure) }\end{array}$ & $\begin{array}{l}\text { Model } 4 \\
\text { (Interaction } \\
\text { term) }\end{array}$ \\
\hline \multicolumn{5}{|c|}{ Regional types (reference: core cities) } \\
\hline Urbanised districts & $\begin{array}{l}-0.006 \\
(0.149)\end{array}$ & $\begin{array}{l}-0.085 \\
(0.148)\end{array}$ & $\begin{array}{l}-0.020 \\
(0.147)\end{array}$ & $\begin{array}{l}-0.066 \\
(0.144)\end{array}$ \\
\hline $\begin{array}{l}\text { Rural districts with } \\
\text { features of concentration }\end{array}$ & $\begin{array}{l}-0.140 \\
(0.296)\end{array}$ & $\begin{array}{l}0.046 \\
(0.305)\end{array}$ & $\begin{array}{l}0.034 \\
(0.299)\end{array}$ & $\begin{array}{l}0.140 \\
(0.293)\end{array}$ \\
\hline $\begin{array}{l}\text { Rural districts, sparsely } \\
\text { populated }\end{array}$ & $\begin{array}{l}-0.028 \\
(0.266)\end{array}$ & $\begin{array}{l}-0.049 \\
(0.267)\end{array}$ & $\begin{array}{l}-0.050 \\
(0.262)\end{array}$ & $\begin{array}{l}-0.121 \\
(0.258)\end{array}$ \\
\hline \multicolumn{5}{|c|}{ Establishment size (reference: $1-49$ ) } \\
\hline $50-449$ & $\begin{array}{l}0.139 * * \\
(0.061)\end{array}$ & $\begin{array}{l}0.082 \\
(0.066)\end{array}$ & $\begin{array}{l}0.117 * \\
(0.066)\end{array}$ & $\begin{array}{l}0.156 * * \\
(0.065)\end{array}$ \\
\hline$>500$ & $\begin{array}{l}0.019 \\
(0.057)\end{array}$ & $\begin{array}{l}-0.050 \\
(0.059)\end{array}$ & $\begin{array}{l}-0.002 \\
(0.060)\end{array}$ & $\begin{array}{l}-0.007 \\
(0.059)\end{array}$ \\
\hline \multicolumn{5}{|c|}{ Sector (reference: agriculture and manufacturing) } \\
\hline Services & $\begin{array}{l}0.012 \\
(0.032)\end{array}$ & $\begin{array}{l}0.008 \\
(0.035)\end{array}$ & $\begin{array}{l}0.001 \\
(0.034)\end{array}$ & $\begin{array}{l}-0.019 \\
(0.034)\end{array}$ \\
\hline Constant & $\begin{array}{l}0.258 \\
(0.419)\end{array}$ & $\begin{array}{l}0.513 \\
(0.435)\end{array}$ & $\begin{array}{l}0.460 \\
(0.426)\end{array}$ & $\begin{array}{l}0.436 \\
(0.417)\end{array}$ \\
\hline Observations & 182 & 182 & 182 & 182 \\
\hline Adjusted $R^{2}$ & 0.3361 & 0.3321 & 0.3591 & 0.3905 \\
\hline
\end{tabular}

Example of interpretation: an increase in the substitution potential of 1 percentage point is related to a decrease in employment growth by $0.09 \%$ (row 1). An increase in physical work exposure by 1 unit is associated with a decrease in employment growth by $0.8 \%$ (row 3 )

Standard errors in parentheses

$* * * p<0.01, * * p<0.05, * p<0.1$

computers and machines and are often assumed to increase in occupations with large proportions of digital tasks. However, the nature of the specific technology seems to be decisive in this relationship (Meyer et al. 2019; Kirchner 2015).

In this article, we assume that whereas the substitution of certain tasks and occupations in the course of digital transformation might be related to lower physical work exposure in some occupations, it is not related to psychosocial work exposure. Because of occupational gender segregation, we analyse this relationship separately for male-dominated and female-dominated occupations. We assume that digital transformation may replace physically demanding tasks mainly performed by men, meaning that a positive relationship between substitution potential and physical work exposure can especially be attributed to substitution potential in maledominated occupations. With regard to psychosocial work demands, we expect to find no clear relationship. We rather expect a general increase in psychosocial work demands in the digital transformation (Schütte and Köper 2013; Morschhäuser et al. 2010), with no relationship to substitution potential. 
Table 7 Relationship between work exposure and substitution potential in 2012 and employment growth between 2012 and 2016 for female-dominated occupations. Source: own calculations, $\mathrm{BeH}$ (2012), BERUFENET (2012), BiBB-BAuA (2012)

\begin{tabular}{|c|c|c|c|c|}
\hline & $\begin{array}{l}\text { Model } 1 \\
\text { (Substitution } \\
\text { potential) }\end{array}$ & $\begin{array}{l}\text { Model } 2 \\
\text { (Work Expo- } \\
\text { sure) }\end{array}$ & $\begin{array}{l}\text { Model } 3 \\
\text { (Substitution } \\
\text { poten- } \\
\text { tial + work } \\
\text { exposure) }\end{array}$ & $\begin{array}{l}\text { Model } 4 \\
\text { (Interaction } \\
\text { term) }\end{array}$ \\
\hline Substitution potential & $\begin{array}{l}0.023 \\
(0.071)\end{array}$ & $\begin{array}{l}- \\
-\end{array}$ & $\begin{array}{l}0.130 \\
(0.105)\end{array}$ & $\begin{array}{l}0.124 \\
(0.122)\end{array}$ \\
\hline \multicolumn{5}{|l|}{ Work exposure } \\
\hline Physical work exposure & - & $\begin{array}{l}0.001 \\
(0.006)\end{array}$ & $\begin{array}{l}0.009 \\
(0.009)\end{array}$ & $\begin{array}{l}-0.001 \\
(0.013)\end{array}$ \\
\hline $\begin{array}{l}\text { Psychosocial work } \\
\text { exposure }\end{array}$ & - & $\begin{array}{l}-0.005 \\
(0.004)\end{array}$ & $\begin{array}{l}-0.009 \\
(0.006)\end{array}$ & $\begin{array}{l}-0.001 \\
(0.009)\end{array}$ \\
\hline \multicolumn{5}{|l|}{ Interaction term } \\
\hline $\begin{array}{l}\text { Substitution potential and } \\
\text { physical work exposure }\end{array}$ & - & - & - & $\begin{array}{l}0.027 \\
(0.030)\end{array}$ \\
\hline $\begin{array}{l}\text { Substitution potential and } \\
\text { psychosocial work } \\
\text { exposure }\end{array}$ & - & - & - & $\begin{array}{l}-0.029 \\
(0.026)\end{array}$ \\
\hline \multicolumn{5}{|l|}{ Age (reference: $\geq 50$ years) } \\
\hline 16 to $<30$ years & $\begin{array}{l}0.122 \\
(0.221)\end{array}$ & $\begin{array}{l}0.187 \\
(0.227)\end{array}$ & $\begin{array}{l}0.283 \\
(0.238)\end{array}$ & $\begin{array}{l}0.447 \\
(0.281)\end{array}$ \\
\hline$\geq 30$ to $<50$ years & $\begin{array}{l}0.360 \\
(0.357)\end{array}$ & $\begin{array}{l}0.452 \\
(0.361)\end{array}$ & $\begin{array}{l}0.654 \\
(0.394)\end{array}$ & $\begin{array}{l}0.771 * \\
(0.420)\end{array}$ \\
\hline \multicolumn{5}{|c|}{ Qualification (reference: low and missing education) } \\
\hline Medium education & $\begin{array}{l}-0.700 \\
(0.744)\end{array}$ & $\begin{array}{l}-0.807 \\
(0.743)\end{array}$ & $\begin{array}{l}-0.673 \\
(0.746)\end{array}$ & $\begin{array}{l}-0.772 \\
(0.842)\end{array}$ \\
\hline High education & $\begin{array}{l}-0.641 \\
(0.728)\end{array}$ & $\begin{array}{l}-0.756 \\
(0.722)\end{array}$ & $\begin{array}{l}-0.598 \\
(0.728)\end{array}$ & $\begin{array}{l}-0.688 \\
(0.818)\end{array}$ \\
\hline Fixed-term contract & $\begin{array}{l}1.341 * * * \\
(0.351)\end{array}$ & $\begin{array}{l}1.212^{* * *} \\
(0.353)\end{array}$ & $\begin{array}{l}1.280 * * * \\
(0.355)\end{array}$ & $\begin{array}{l}1.121 * * * \\
(0.385)\end{array}$ \\
\hline Full-time employment & $\begin{array}{l}0.461 * * \\
(0.203)\end{array}$ & $\begin{array}{l}0.403^{*} \\
(0.213)\end{array}$ & $\begin{array}{l}0.363^{*} \\
(0.214)\end{array}$ & $\begin{array}{l}0.282 \\
(0.227)\end{array}$ \\
\hline Minor employment & $\begin{array}{l}-0.333 \\
(0.379)\end{array}$ & $\begin{array}{l}-0.374 \\
(0.375)\end{array}$ & $\begin{array}{l}-0.331 \\
(0.374)\end{array}$ & $\begin{array}{l}-0.388 \\
(0.431)\end{array}$ \\
\hline Foreign nationality & $\begin{array}{l}-0.319 \\
(0.661)\end{array}$ & $\begin{array}{l}-0.379 \\
(0.679)\end{array}$ & $\begin{array}{l}-0.244 \\
(0.684)\end{array}$ & $\begin{array}{l}-0.290 \\
(0.751)\end{array}$ \\
\hline $\begin{array}{l}\text { Eastern German } \\
\text { residency }\end{array}$ & $\begin{array}{l}0.549 \\
(0.368)\end{array}$ & $\begin{array}{l}0.569 \\
(0.373)\end{array}$ & $\begin{array}{l}0.659^{*} \\
(0.377)\end{array}$ & $\begin{array}{l}0.689 * \\
(0.382)\end{array}$ \\
\hline
\end{tabular}


Table 7 (Continued)

\begin{tabular}{|c|c|c|c|c|}
\hline & $\begin{array}{l}\text { Model } 1 \\
\text { (Substitution } \\
\text { potential) }\end{array}$ & $\begin{array}{l}\text { Model } 2 \\
\text { (Work Expo- } \\
\text { sure) }\end{array}$ & $\begin{array}{l}\text { Model } 3 \\
\text { (Substitution } \\
\text { poten- } \\
\text { tial + work } \\
\text { exposure) }\end{array}$ & $\begin{array}{l}\text { Model } 4 \\
\text { (Interaction } \\
\text { term) }\end{array}$ \\
\hline \multicolumn{5}{|c|}{ Regional types (reference: core cities) } \\
\hline Urbanised districts & $\begin{array}{l}2.422 * * * \\
(0.717)\end{array}$ & $\begin{array}{l}2.256 * * * \\
(0.727)\end{array}$ & $\begin{array}{l}2.132 * * * \\
(0.728)\end{array}$ & $\begin{array}{l}2.060 * * * \\
(0.744)\end{array}$ \\
\hline $\begin{array}{l}\text { Rural districts with } \\
\text { features of concentration }\end{array}$ & $\begin{array}{l}-2.847^{*} \\
(1.593)\end{array}$ & $\begin{array}{l}-2.458 \\
(1.639)\end{array}$ & $\begin{array}{l}-1.909 \\
(1.687)\end{array}$ & $\begin{array}{l}-1.669 \\
(1.718)\end{array}$ \\
\hline $\begin{array}{l}\text { Rural districts, sparsely } \\
\text { populated }\end{array}$ & $\begin{array}{l}2.343 \\
(1.392)\end{array}$ & $\begin{array}{l}2.131 \\
(1.399)\end{array}$ & $\begin{array}{l}1.832 \\
(1.410)\end{array}$ & $\begin{array}{l}1.616 \\
(1.440)\end{array}$ \\
\hline \multicolumn{5}{|c|}{ Establishment size (reference: $1-49$ ) } \\
\hline $50-449$ & $\begin{array}{l}-0.010 \\
(0.121)\end{array}$ & $\begin{array}{l}0.016 \\
(0.118)\end{array}$ & $\begin{array}{l}0.105 \\
(0.137)\end{array}$ & $\begin{array}{l}0.137 \\
(0.153)\end{array}$ \\
\hline$>500$ & $\begin{array}{l}0.135^{*} \\
(0.080)\end{array}$ & $\begin{array}{l}0.149 * \\
(0.083)\end{array}$ & $\begin{array}{l}0.160 * \\
(0.083)\end{array}$ & $\begin{array}{l}0.165 * \\
(0.089)\end{array}$ \\
\hline \multicolumn{5}{|c|}{ Sector (reference: agriculture and manufacturing) } \\
\hline Services & $\begin{array}{l}0.197 * \\
(0.113)\end{array}$ & $\begin{array}{l}0.210 * \\
(0.104)\end{array}$ & $\begin{array}{l}0.304 * * \\
(0.128)\end{array}$ & $\begin{array}{l}0.303 * * \\
(0.132)\end{array}$ \\
\hline Constant & $\begin{array}{l}-0.954 \\
(0.785)\end{array}$ & $\begin{array}{l}-0.828 \\
(0.719)\end{array}$ & $\begin{array}{l}-1.261 \\
(0.795)\end{array}$ & $\begin{array}{l}-1.172 \\
(0.894)\end{array}$ \\
\hline Observations & 56 & 56 & 56 & 56 \\
\hline Adjusted $R^{2}$ & 0.6157 & 0.6203 & 0.6255 & 0.6184 \\
\hline
\end{tabular}

Example of interpretation: an increase in the substitution potential of 1 percentage point is related to a decrease in employment growth by $0.02 \%$ (row 1, not significant). An increase in physical work exposure by 1 unit is associated with a decrease in employment growth by $0.9 \%$ (row 3, not significant)

Standard errors in parentheses

$* * * p<0.01, * * p<0.05, * p<0.1$

For our analyses, we combine different data sets at the occupational level. Based on administrative data on employees in Germany, we distinguish between maledominated, female-dominated and gender-integrated occupations. We measure the degree of digital transformation by the occupation-specific substitution potential (Dengler and Matthes 2018a). Gender-specific work exposure information is obtained from the 2012 BIBB/BAuA employment survey and is based on an index of occupational job demands by Kroll (2011).

The empirical results are mixed. First, we find a general, positive relationship between substitution potential and physical work exposure. However, the relationship seems to depend on further occupational characteristics. As expected, we find no relationship between digital transformation and psychosocial work exposure. Regarding gender-specific occupations, our results indicate-in line with our hypothesis-that working conditions in male-dominated occupations are more likely to improve than working conditions in female-dominated occupations owing to digital transformation. The findings imply that horizontal gender segregation may contribute to a segregation of work exposure caused by digital transformation (Kirchner 2015). 
Social inequality between men and women, as well as between different occupational groups, may increase because of digital transformation, as work may become easier for men but not for women. However, digital transformation is progressing at an almost unpredictable speed; thus, women's occupations could be more affected in the future, supporting a healthy working environment and leading to new forms of workload. Based on our findings, we support both Kutzner and Schnier (2017) and Hauer (2016), who rightly note that gender relations in the digital transformation process must be (re)designed to prevent existing inequalities from being exacerbated.

As we do not know the extent to which substitution potential and work exposure are related to occupation-specific employment growth, we carry out additional analyses. Empirical evidence shows substitution potential to be negatively related to employment growth; this negative relationship can also be found for physical work exposure, but not for substitution potential and physical work exposure. Hence, physically demanding jobs seem to downsize independently of the digital transformation. This result can be found for the total sample and for male-dominated occupations. For female-dominated occupations, we find no significant results. Nevertheless, further analysis is necessary, as we can only consider a short observation period of 4 years (2012-2016).

To our knowledge, the present study is the first to analyse the relationship between substitution potential in the course of digital transformation and work exposure in gender-specific occupations. We use an innovative measure for the degree of digital transformation, namely the substitution potential of Dengler and Matthes (2018a), who calculated the share of routine tasks that can potentially be substituted by computers or computer-controlled machines. Although the distinction between routine and non-routine tasks seems to be the categorical foundation of international labour market research (Autor et al. 2003), some authors rightly argue that the scope of routine and non-routine tasks depends to a large extent on the framework conditions of work organisation and may differ significantly within occupations (Pfeiffer 2018). Accordingly, Pfeiffer and Suphan (2015) emphasise the heterogeneity of tasks within occupations. Generalizable findings at an occupational level cannot take this heterogeneity into account, and the possibility of an ecological fallacy cannot be completely ruled out in analyses at the aggregated level (Gschwend 2006). However, we measure substitution potential for different occupations; thus, we also conduct the analyses at the occupational level. Further analysis conducted at the individual level should also take into account other indicators of digital transformation, such as the distribution of digital tools at the workplace, to further analyse how work exposure will develop in an increasingly digitalised working world.

Heterogeneity within occupations can also be assumed for the measurements of work exposure, which are defined rather broadly and comprise different aspects of both physical and psychosocial work exposure. A more detailed, workplace-specific examination of different work demands would help to take a more differentiated look at the context to be able to provide advice on the design of different workplaces. Thus, we ignore specific features of individual technologies and their possible impact on the physical and psychosocial work exposure of individuals.

Furthermore, we analyse the relationship between digital transformation and gender-specific work exposure only for the year 2012, and the analyses do not allow for 
any causal interpretation. With variance over time, we could analyse this issue using more advanced econometric methods to obtain causal effects. We therefore cannot consider how non-routine tasks are changing through the use of digital technologies, or how digital technologies are related to new and demanding work requirements, such as work intensity or the blurring of work and private lives.

Acknowledgements We are indebted to Silke Tophoven and the two anonymous reviewers for their excellent comments.

Funding Open Access funding provided by Projekt DEAL.

Open Access This article is licensed under a Creative Commons Attribution 4.0 International License, which permits use, sharing, adaptation, distribution and reproduction in any medium or format, as long as you give appropriate credit to the original author(s) and the source, provide a link to the Creative Commons licence, and indicate if changes were made. The images or other third party material in this article are included in the article's Creative Commons licence, unless indicated otherwise in a credit line to the material. If material is not included in the article's Creative Commons licence and your intended use is not permitted by statutory regulation or exceeds the permitted use, you will need to obtain permission directly from the copyright holder. To view a copy of this licence, visit http://creativecommons.org/licenses/by/4. $0 /$.

\section{References}

Achatz, Juliane. 2008. Geschlechtersegregation im Arbeitsmarkt. In Arbeitsmarktsoziologie. Probleme, Theorien, empirische Befunde, eds. Martin Abraham and Thomas Hinz, 263-301. Wiesbaden: VS Verlag für Sozialwissenschaften.

Adolph, Lars, Isabel Rothe and Armin Windel. 2016. Arbeit in der digitalen Welt - Mensch im Mittelpunkt. Zeitschrift für Arbeitswissenschaft 70:77-81.

Ahlers, Elka. 2016. Flexible and Remote Work in the Context of Digitization and Occupational Health. International Journal of Labour Research 8(1-2):85-101.

Allmendinger, Jutta, and Richard J. Hackman. 1995. The More, the Better? Social Forces 74:423-460.

Arnold, Daniel, Sebastian Butschek, Susanne Steffes and Dana Müller. 2016. Digitalisierung am Arbeitsplatz. Aktuelle Ergebnisse einer Betriebs- und Beschäftigtenbefragung. Berlin: BMAS.

Arntz, Melanie, Terry Gregory and Ulrich Zierahn. 2016. The Risk of Automation for Jobs in OECD Countries-A Comparative Analysis. OECD Social, Employment and Migration-Working Papers No. 189.

Arntz, Melanie, Terry Gregory and Ulrich Zierahn. 2017. Revisiting the risk of automation. Economic Letters 159:157-160.

Autor, David H., Frank Levy and Richard J. Murnane. 2003. The Skill Content of Recent Technological Change: An Empirical Exploration. The Quarterly Journal of Economics 118:1279-1333.

Beermann, Beate, Frank Brenscheidt and Anke Siefer. 2008. Unterschiede in den Arbeitsbedingungen und -belastungen von Frauen und Männern. In Fehlzeiten-Report 2007: Arbeit, Geschlecht und Gesundheit Zahlen, Daten, Analysen aus allen Branchen der Wirtschaft, eds. Bernhard Badura, Helmut Schröder and Christian Vetter, 69-82. Berlin, Heidelberg: Springer Berlin Heidelberg.

Böhm, Stephan Alexander, Kirill Bourovoi, Anna Brzykcy, Lars Martin Kreissner and Christoph Breier. 2016. Auswirkungen der Digitalisierung auf die Gesundheit von Berufstätigen: Eine bevölkerungsrepräsentative Studie in der Bundesrepublik Deutschland. St. Gallen: Universität St. Gallen.

Brenscheidt, Simone, Anke Siefer, Heike Hinnenkamp and Lena Hünefeld. 2018. Arbeitswelt im Wandel: Zahlen - Daten - Fakten. Dortmund: Bundesanstalt für Arbeitsschutz und Arbeitsmedizin.

Busch-Heinzmann, Anne. 2015. Frauenberufe, Männerberufe und die „Drehtür“ - Ausmaß und Implikationen für West- und Ostdeutschland. WSI Mitteilungen 68:871-582.

Büssing, Andre. 1987. Arbeitsplatzunsicherheit und Antizipation von Arbeitslosigkeit als Stadien des Arbeitslosigkeitsprozesses. Soziale Welt 38:309-329.

Carstensen, Tanja. 2016. Ambivalenzen digitaler Kommunikation am Arbeitsplatz. Aus Politik und Zeitgeschichte 18-19:39-46. 
Carstensen, Tanja. 2015. Im WWW nichts Neues. Warum die Digitalisierung der Arbeit Geschlechterverhältnisse kaum berührt. luXem-burg. Gesellschaftsanalyse und linke Praxis 3/2015.

Dengler, Katharina, and Britta Matthes. 2016. Auswirkungen der Digitalisierung auf die Arbeitswelt: Substituierbarkeitspotenziale nach Geschlecht. Aktuelle Berichte des IAB 2016.

Dengler, Katharina, and Britta Matthes. 2018a. The impacts of digital transformation on the labour market: Substitution potentials of occupations in Germany. Technological Forecasting \& Social Change 137:304-316.

Dengler, Katharina, and Britta Matthes. 2018b. Substituierbarkeitspotenziale von Berufen - Wenige Berufsbilder halten mit der Digitalisierung Schritt. IAB Kurzbericht 4/2018.

Eng, Amanda, Andrea 't Mannetje, Dave Mclean, Lis Ellison-Loschmann, Soo Cheng and Neil Pearce. 2011. Gender differences in occupational exposure patterns. Occupational and Environmental Medicine 68:888-894.

EU-OSHA European Union information agency for occupational safety and health. 2018. Women and safety and health at work. Retrieved from https://osha.europa.eu/en/themes/women-and-health-work (Accessed: 10 Oct. 2018).

Ferrie, Jane. 2006. Gesundheitliche Folgen der Arbeitsplatzunsicherheit. In Fehlzeiten-Report 2005, eds. Bernhard. Badura, Henner Schellschmidt and Christian Vetter, 93-123. Berlin, Heidelberg: Springer.

Fitzenberger, Bernd, Aderonke Osikominu and Robert Völter. 2005. Imputation Rules to Improve the Education Variable in the Subsample. Mannheim. Online: http://doku.iab.de/fdz/events/2005/Osikominu. pdf.

Frey, Carl Benedikt, and Michael A. Osborne. 2017. The future of employment: How susceptible are jobs to computerisation? Technological Forecasting \& Social Change 114:254-280.

Gallie, Duncan, Alan Felstead, Francis Green and Hande Inanc. 2017. The hidden face of job insecurity. Work, Employment and Society 31:36-53.

Gschwend, Thomas. 2006. Ökologische Inferenz. In Methoden der Politikwissenschaft: neuere qualitative und quantitative Analyseverfahren, eds. Joachim Behnke, Thomas Gschwend, Delia Schindler and Kai-Uwe Schnapp, 227-237. Baden-Baden: Nomos.

Guhlemann, Kerstin, Arne Georg and Arne Katenkamp. 2018. Der Mensch im Mittelpunkt oder im Weg? Grenzen und Potenziale menschengerechter Arbeitsgestaltung in der digitalen Transformation. WSI Mitteilungen 71:211-218.

Hauer, Gerlinde. 2016. Digitalisierung - Selbstläufer Richtung Gleichstellung? Von der Hartnäckigkeit geschlechtstypischer Zuschreibungen, dem Strukturwandel in wichtigen Frauenbranchen und der Chance sozialer Innovation. WISO 39:171-183.

Hausmann, Ann-Christin, and Corinna Kleinert. 2014. Berufliche Segregation auf dem Arbeitsmarkt: Männer- und Frauendomänen kaum verändert. IAB-Kurzbericht 9/2014.

Holler, Markus. 2017. DGB-Index Gute Arbeit. Verbreitung, Folgen und Gestaltungsaspekte der Digitalisierung in der Arbeitswelt. Berlin. Institut DGB-Index Gute Arbeit.

Junghanns, Gisa, and Norbert Kersten. 2019. Informationsüberflutung am Arbeitsplatz. Zentralblatt für Arbeitsmedizin, Arbeitsschutz und Ergonomie: online first: https://doi.org/10.1007/s40664-01900370-w.

Kirchner, Stefan. 2015. Konturen der digitalen Arbeitswelt. Kölner Zeitschrift für Soziologie und Sozialpsychologie 67:763-791.

Köper, Birgit, and Gabriele Richter. 2016. Restrukturierung und Gesundheit. In Fehlzeiten-Report 2016, eds. Bernhard Badura, Antje Ducki, Helmut Schröder, Joachim Klose and Markus Meyer, 159-170. Berlin: Springer.

Kroll, Lars Eric. 2011. Konstruktion und Validierung eines allgemeinen Index für die Arbeitsbelastung in beruflichen Tätigkeiten anhand von ISCO-88 und KldB-92. MDA-Methoden, Daten, Analysen 5:63-90.

Kroll, Lars Eric, and Thomas Lampert. 2012. Arbeitslosigkeit, prekäre Beschäftigung und Gesundheit. GBE kompakt 3.

Kroll, Lars Eric, Stephan Müters and Nico Dragano. 2011. Arbeitsbelastungen und Gesundheit. Berlin: Robert Koch-Institut.

Kutzner, Edelgard, and Victoria Schnier. 2017. Geschlechterverhältnisse in Digitalisierungsprozessen von Arbeit: Konzeptionelle Überlegungen und empirische Fragestellungen. Arbeit 26:137-157.

Leijon, Margareta, Gunnel Hensing and Kristina Alexanderson. 2004. Sickness absence due to musculoskeletal diagnoses: association with occupational gender segregation. Scandinavian Journal of Social Medicine 32:94-101. 
Lott, Yvonne. 2016. Fördert die Digitalisierung Geschlechtergerechtigkeit? In Digitalisierung der Arbeitswelt. Mitbestimmungs-Report, eds. Nadine Absenger, Elke Ahlers, Alexander Herzog-Stein, Yvonne Lott, Manuela Maschke and Marc Schietinger, 7-8. Düsseldorf: Hans-Böckler-Stiftung.

Mastekaasa, Arne. 2005. Sickness absence in female- and male-dominated occupations and workplaces. Social Science \& Medicine 60:2261-2272.

Mastekaasa, Arne, and Anne May Melsom. 2014. Occupational Segregation and Gender Differences in Sickness Absence: Evidence from 17 European Countries. European Sociological Review 30:582-594.

Meyer, Sophie-Charlotte, and Lena Hünefeld. 2018. Berufliche Computernutzung: Chancen und Risiken für Erwerbstätige. Dortmund. Bundesanstalt für Arbeitsschutz und Arbeitsmedizin (BAuA). 25.

Meyer, Sophie-Charlotte, Anita Tisch and Lena Hünefeld. 2019. Arbeitsintensivierung und Handlungsspielraum in digitalisierten Arbeitswelten - Herausforderung für das Wohlbefinden von Beschäftigten? Industrielle Beziehungen 26:207-231.

Mohr, Gisela. 2000. The changing significance of different stressors after the announcement of bankruptcy: a longitudinal investigation with special emphasis on job insecurity. Journal of Organizational Behavior 21:337-359.

Morschhäuser, Martina, Michael Ertel and Uwe Lenhardt. 2010. Psychische Arbeitsbelastungen in Deutschland: Schwerpunkte - Trends - betriebliche Umgangsweisen. WSI-Mitteilungen 63:335-342.

Müller-Thur, Kathrin, Peter Angerer, U. Körner and Nico Dragano. 2018. Arbeit mit digitalen Technologien, psychosoziale Belastungen und potenzielle gesundheitliche Konsequenzen: Wo gibt es Zusammenhänge? ASU Arbeitsmedizin Sozialmedizin Umweltmedizin 52:388-391.

Pfeiffer, Sabine. 2018. Die Quantifizierung von Nicht-Routine. Zur ökologischen Validierung des Arbeitsvermögen-Index - und einem anderen Blick auf das Ersetzungspotenzial von Produktionsarbeit. Arbeit - Zeitschrift für Arbeitsforschung, Arbeitsgestaltung und Arbeitspolitik 27:213-237.

Pfeiffer, Sabine, and Anne Suphan. 2015. Erfahrung oder Routine? Ein anderer Blick auf das Verhältnis von Industrie 4.0 und Beschäftigung. BWP Berufsbildung in Wissenschaft und Praxis 44(6):21-25.

Quinlan, Michael, Claire Mayhew and Philip Bohle. 2001. The Global Expansion of Precarious Employment, Work Disorganization, and Consequences for Occupational Health: A Review of Recent Research. International Journal of Health Services 31:335-414.

Reinert, Dietmar. 2016. The future of OSH: a wealth of chances and risks. Industrial health 54:387-388.

Rohrbach-Schmidt, Daniela, and Anja Hall. 2013. BIBB/BAuA-Erwerbstätigenbefragung 2012. BIBBFDZ Daten- und Methodenberichte 1/2013.

Rosa, Hartmut. 2005. Beschleunigung: die Veränderung der Zeitstrukturen in der Moderne. Berlin: Suhrkamp.

Roxburgh, Susan. 1996. Gender Differences in Work and Well-Being: Effects of Exposure and Vulnerability. Journal of Health and Social Behavior 37:265-277.

Schmucker, Rolf. 2015. Geschlechtsspezifische Arbeitsintensivierung. In Wie weiblich ist die Arbeit der Zunkunft? Chancen und Risiken der Digitalisierung für Frauen, ed. Deutscher Gewerkschaftsbund, 14-15. Berlin: DGB.

Schütte, Martin, and Birgit Köper. 2013. Veränderung der Arbeit. Bundesgesundheitsblatt 56:422-429.

Sparks, Kate, Brian Faragher and Cary L Cooper. 2001. Well-being and occupational health in the 21st century workplace. Journal of Occupational and Organizational Psychology 74:489-509.

Stab, Nicole, and Nika Schulz-Dadaczynski. 2017. Arbeitsintensität: Ein Überblick zu Zusammenhängen mit Beanspruchungsfolgen und Gestaltungsempfehlungen. Zeitschrift für Arbeitswissenschaft $71: 14-25$.

Tophoven, Silke, and Anita Tisch. 2016. Dimensionen prekärer Beschäftigung und Gesundheit im mittleren Lebensalter. WSI Mitteilungen 2016:105-112.

Tophoven, Silke, Jean-Baptist Du Prel, Richard Peter and Veronika Kretschmer. 2015. Working in genderdominated occupations and depressive symptoms: findings from the two age cohorts of the lidA study. Journal for Labour Market Research 48:247-262.

Katharina Dengler 1983, Dr. rer. pol., senior researcher at the Institute for Employment Research (IAB). Areas of research: empirical labour economics, the task-based approach and the impacts of digital transformation on the labour market. Recent publication: The impacts of digital transformation on the labour market. Substitution potentials of occupations in Germany, Technological Forecasting and Social Change, Vol. 137, 2018 (with B. Matthes). 
Anita Tisch 1983, Dr. rer. pol., head of research unit "Changing World of Work" at the Federal Institute for "Occupational Safety and Health" (BAuA). Her research interest involves the relationship between working time and flexibilisation, organisational and demographical change, as well as digitalisation with working conditions and health. Furthermore, she is involved in the collection and analyses of large survey data. Recent publications: Work intensification and autonomy in the digitized working world-A challenge for the well-being of employees? Industrielle Beziehungen 26, 2019 (with S. Meyer and L. Hünefeld); Age and gender differences in the impact of labour-market transitions on subjective health in Germany. Scandinavian Journal of Public Health 46, 2018 (with S. Unger and S. Tophoven). 